\title{
21. ELEMENTAL AND STABLE-ISOTOPE COMPOSITION OF PORE WATERS AND CARBONATE SEDIMENTS FROM DEEP SEA DRILLING PROJECT SITES 501/504 AND 5051
}

\author{
M. J. Mottl, Woods Hole Oceanographic Institution, Woods Hole, Massachusetts \\ J. R. Lawrence, Lamont-Doherty Geological Observatory of Columbia University, Palisades, New York \\ and \\ L. D. Keigwin, Woods Hole Oceanographic Institution, Woods Hole, Massachusetts
}

\begin{abstract}
Two sites on the southern flank of the Costa Rica Rift were drilled on DSDP Legs 68 and 69, one on crust 3.9 m.y. old and the other on crust $5.9 \mathrm{~m}$.y. old. The basement of the younger site is effectively cooled by the circulation of seawater. The basement of the older site has been sealed by sediment, and an interval in the uppermost 560 meters of basement recently reheated to temperatures of 60 to $120^{\circ} \mathrm{C}$.

Although the thickness of the sediments at the two sites is similar (150-240 m versus $270 \mathrm{~m})$, the much rougher basement topography at the younger Site 505 produces occasional basement outcrops, through which 80 to $90 \%$ of the total heat loss apparently occurs by advection of warm seawater. This seawater has been heated only slightly, however; the temperature at the base of the sediments is only $9^{\circ} \mathrm{C}$. Changes in its composition due to reaction with the basement basalts are negligible, as indicated by profiles of sediment pore water chemistry. Bacterial sulfate reduction in the sediments produces a decrease in $\mathrm{SO}_{4}$ (and $\mathrm{Ca}$ ) and an increase in alkalinity (and $\mathrm{Sr}$ and $\mathrm{NH}_{3}$ ) as depth increases to an intermediate level, but at deeper levels these trends reverse, and all of these species plus $\mathrm{Mg}, \mathrm{K}, \mathrm{Na}$, and chlorinity approach seawater values near basement. $\mathrm{Si}$, however, is higher, and $\mathrm{Li}$ may be lower.

At the older site, Site 501/504, where heat loss is entirely by conduction, the temperature at the sediment/basement contact is $59^{\circ} \mathrm{C}$. Sediment pore water chemistry is heavily affected by reaction with the basaltic basement, as indicated by large decreases in $\delta^{18} \mathrm{O}, \mathrm{Mg}$, alkalinity, $\mathrm{Na}$, and $\mathrm{K}$ and an increase in $\mathrm{Ca}$ with increasing depth. The size of the changes in $\delta^{18} \mathrm{O}, \mathrm{Mg}$, alkalinity, $\mathrm{Ca}, \mathrm{Sr}$, and $\mathrm{SO}_{4}$ varies laterally over 500 meters, indicating lateral gradients in pore water chemistry that are nearly as large as the vertical gradients. The lateral gradients are believed to result from similar lateral gradients in the composition of the basement formation water, which propagate upward through the sediments by diffusion.

A model of the $\delta^{18} \mathrm{O}$ profile suggests that the basement at Site 501/504 was sealed off from advection about $1 \mathrm{~m} . \mathrm{y}$. ago, so that reaction rates began to dominate the basement pore water chemistry. A limestone-chert diagenetic front began to move upward through the lower sediments less than $200,000 \mathrm{yr}$. ago.
\end{abstract}

\section{INTRODUCTION}

On DSDP Legs 68 and 69 two sites were drilled on the southern flank of the Costa Rica Rift (Fig. 1) to study hydrothermal processes in young oceanic crust. The two sites are situated in contrasting heat flow regimes: heat loss at the younger site (Site 505) is mainly advective, whereas heat loss at the older site (Site 501/504) is entirely by conduction through the sediment column. The contrast, which results from the much rougher basement topography at Site 505, has a profound effect on the sediment pore water chemistry. Composition versus depth profiles at both sites have unusual features not seen before in DSDP holes. These features result largely from the temperature and extent of reaction with basaltic rocks of seawater flowing through the basement beneath the sediment. The effect of the basement reactions on the chemistry of the sediment pore water is obvious in spite of a complicated overprint due to diagenetic reactions within the sediments themselves.

\section{GEOLOGIC SETTING}

Site 505 is situated on 3.9 m.y. old crust in an eastwest trending trough that is $15 \mathrm{~km}$ wide, has a floor 2 to

\footnotetext{
${ }^{1}$ Cann, J. R., Langseth, M. G., Honnorez, J., Von Herzen, R. P., White, S. M., et al., Init. Repts. DSDP, 69: Washington (U.S. Govt. Printing Office).
}

$3 \mathrm{~km}$ wide, and is bounded by ridges 300 to 400 meters high. Although the sediment in the trough is 130 to 240 meters thick, the basement crops out along the larger escarpments, most of which have throws of 100 to 200 meters. These outcrops apparently act as conduits for the exit of warm, circulating seawater, because the conductive heat flow in this area is only 10 to $20 \%$ of that theoretically predicted for crust of this age. The conductive heat flow measurements indicate that the temperature at the top of the basement, which has been effectively cooled by the circulating water, is only $9^{\circ} \mathrm{C}$ (Langseth et al., this volume).

Sites 501 and 504, $80 \mathrm{~km}$ south of Site 505, are within 300 meters of each other on crust 5.9 m.y. old. The sediment thickness is greater here (about $270 \mathrm{~m}$ ) and more uniform. The basement is abnormally smooth and unfractured compared with the crust immediately to the north and south. Maximum throws on the faults, which produce small escarpments, are probably less than 100 meters. The conductive heat flow measured here is essentially equal to the total heat flow predicted for crust this age, indicating that the sedimentary section has effectively capped the smooth basement, preventing heat loss by advection. The heat flow data indicate that the temperature of the sedimentary layers has reached a conductive equilibrium, which requires a thermal rebound in the crust to a temperature of 60 to $90^{\circ} \mathrm{C}$ at the 


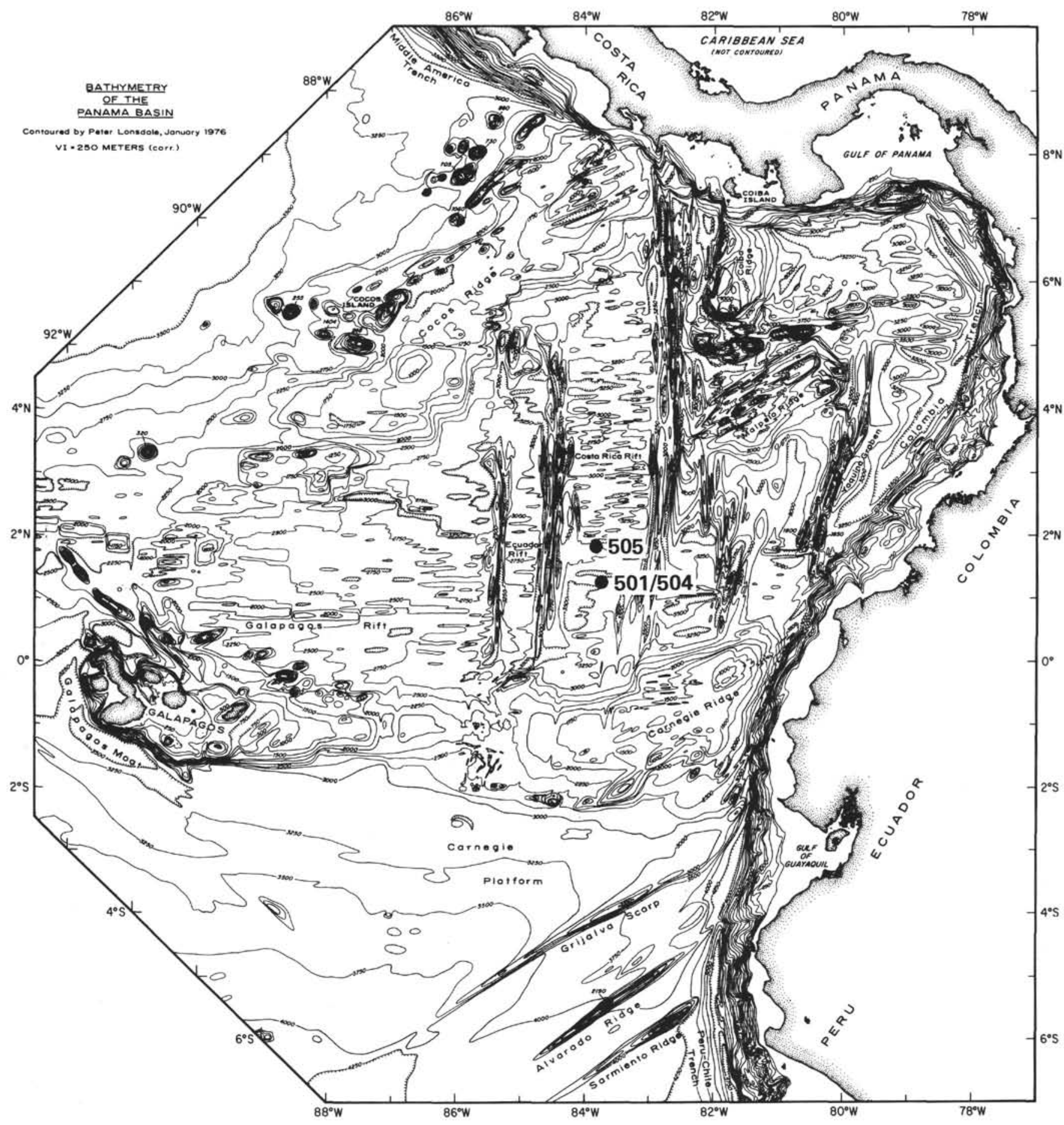

Figure 1. Location of Sites 501, 504, and 505 on the southern flank of the Costa Rica Rift, Panama Basin. Bathymetry from Lonsdale and Klitgord (1978). Contour interval $=250 \mathrm{~m}$.

top of the basement. The wide range of this temperature estimate results from the presence of isolated heat flow highs in the area. Site 501/504 is not located over such a high, and the temperature at the sediment/basement contact was found to be $59^{\circ} \mathrm{C}$ (Becker et al., this volume).

The sediments at all these sites are predominantly siliceous nannofossil ooze, with minor amounts of windblown clay and volcanic ash. $\mathrm{CaCO}_{3}$ content increases with increasing depth in all holes to values near base- ment of 60 to $70 \%$. The most striking difference between the sediment at Site 505 and that at Site 501/504 is diagenetic and results from the higher temperature of the crust at the latter site. The sediments from Hole 505, where heat flow is low, show only a slight consolidation from ooze to chalk in the lower 22 meters of the 232 meter-thick section. In contrast, Site 501/504 in the high heat flow area shows two distinct diagenetic boundaries, from ooze to chalk at a depth of 143 meters and from 
chalk to cherty limestone intercalated with chert at 235 meters. (The basement is at 264 to $274 \mathrm{~m}$.)

\section{SAMPLING METHODS}

Sediments were recovered by both rotary drilling and hydraulic piston coring. Sediment pore waters were sampled by using both the standard squeezing technique and the Barnes in situ sampler in conjunction with the Uyeda-Kinoshita (DSDP-Tokyo) downhole temperature probe (Table 1). This probe projects through the bit and penetrates about 1 meter into the sediments at the depth drilled or washed. The water sample flows into the Barnes tool under hydrostatic pressure through the timer-operated valve and a stainless steel filter screen, displacing distilled water from a copper and stainless steel coil in series into an overflow cylinder with a pressure-relief valve. The prime aliquot from the steel coil is thus usually undiluted pore water, whereas the overflow aliquot is diluted with the distilled water displaced from the coils. Both aliquots have been analyzed for some chemical species to detect the effects, if any, of precipitation and oxidation in one or the other aliquot after sampling.

Hole 505 subcores were cooled to 6.8 to $10.5^{\circ} \mathrm{C}$ prior to squeezing to approximate the in situ temperatures of 2 to $8^{\circ} \mathrm{C}$. The Site $501 / 504$ subcores were squeezed at 20 to $24^{\circ} \mathrm{C}$, although the in situ temperatures varied (approximately linearly) from $2^{\circ} \mathrm{C}$ at the seafloor to $59^{\circ} \mathrm{C}$ at the basement contact. The depth interval that corresponds to temperatures from 20 to $24^{\circ} \mathrm{C}$ is approximately 90 to 115 meters.

\section{ANALYTICAL METHODS}

All samples were filtered through $0.45-\mu \mathrm{m}$ cellulose membrane filters and analyzed in the shipboard laboratory for $\mathrm{pH}$, salinity (via refractive index), chlorinity, alkalinity, $\mathrm{Ca}$, and $\mathrm{Mg}$ using standard titration techniques (Gieskes, 1974). Shore-based analyses of K, Li, Sr, and $\mathrm{Mn}$ were made by flame atomic absorption spectrophotometry. $\mathrm{SO}_{4}$ was analyzed by polarography (Luther and Meyerson, 1975); $\mathrm{Fe}$, $\mathrm{NH}_{3}$, and $\mathrm{Si}$ by colorimetry; and $\delta^{18} \mathrm{O}$ and $\delta \mathrm{D}$ by mass spectrometry. $\mathrm{Na}$ was calculated from charge balance. Results and uncertainties are given in Tables 2 and 3.

\section{RESULTS AND DISCUSSION}

\section{Site $\mathbf{5 0 5}$}

The profiles showing the change in pore water composition with increasing depth in Hole 505 are unusual in that many chemical species reach a maximum or minimum concentration at an intermediate level in the column of sediment and then return to nearly seawater values at basement.

This characteristic is most clearly shown by sulfate, alkalinity, $\mathrm{Ca}, \mathrm{Mg}$, and $\mathrm{NH}_{3}$ (Fig. 2). In the upper 100 meters of the sediments, sulfate decreases almost linearly with depth, alkalinity and $\mathrm{NH}_{3}$ increase to many

Table 1. Sediment and sediment pore water sampling at Sites 501/504 and 505 .

\begin{tabular}{|c|c|c|c|c|}
\hline Leg & Hole & $\begin{array}{l}\text { Depth of } \\
\text { Basement } \\
\text { below } \\
\text { Seafloor } \\
\text { (m) }\end{array}$ & $\begin{array}{l}\text { Depth and Continuity of } \\
\text { Sampling }{ }^{\mathrm{a}}\end{array}$ & $\begin{array}{l}\text { Number and Type of } \\
\text { Pore Water Samples }\end{array}$ \\
\hline 68 & 501 & 264 & Spot cored to basement & 8 squeezed \\
\hline 69 & 504 & - & Cored to chert at $237 \mathrm{~m}^{\mathrm{b}}$ & 17 squeezed \\
\hline 69 & 504A & 264 & Cored 227 to $264 \mathrm{~m}$ & $\begin{array}{l}2 \text { squeezed, } \\
1 \text { in situc }\end{array}$ \\
\hline 69 & 504B & 274.5 & Cored lower $14 \mathrm{~m}$ & 1 squeezed \\
\hline 69 & $504 \mathrm{C}$ & - & Noned & 4 in situ \\
\hline 69 & 505 & 232 & Cored to basement & $\begin{array}{l}16 \text { squeezed, } \\
4 \text { in situ }\end{array}$ \\
\hline
\end{tabular}

\footnotetext{
${ }^{a}$ Rotary drilling was used except where noted otherwise.

b Hydraulic piston coring.

c In situ samples were taken with the Barnes tool.

$\mathrm{d}$ Washed to $220 \mathrm{~m}$.
}

times the seawater value, $\mathrm{Ca}$ decreases greatly, and $\mathrm{Mg}$ (and $\mathrm{Mg} / \mathrm{Cl}$ ) increases slightly. At depths below 100 meters all these trends reverse, and the sediment pore water composition closely approaches that of seawater at the sediment/basement contact.

The profiles for these chemical species in the upper 100 meters are similar to those that have been observed at DSDP sites in rapidly deposited, organic-rich hemipelagic sediments (Sayles and Manheim, 1975). The reduction in sulfate and increase in alkalinity result from bacterial sulfate reduction utilizing organic matter:

$$
2 \mathrm{CH}_{2} \mathrm{O}+\mathrm{SO}_{4}^{2-}=\mathrm{H}_{2} \mathrm{~S}+2 \mathrm{HCO}_{3}^{-}
$$

Sediment in the interval from 100.3 to 100.5 meters below the seafloor emitted gas bubbles and an intense odor of $\mathrm{H}_{2} \mathrm{~S}$ when the core was split, indicating that sulfate reduction is probably most active at that depth. The progressive depletion of $\mathrm{Ca}$ in the upper 100 meters is doubtless due to calcite precipitation in response to the increase in alkalinity:

$$
\mathrm{Ca}^{2+}+2 \mathrm{HCO}_{3}^{-}=\mathrm{CaCO}_{3}+\mathrm{H}_{2} \mathrm{O}+\mathrm{CO}_{2}
$$

When the slight $\mathrm{Mg}$ increase is included, the changes in sulfate, alkalinity, and $\mathrm{Ca}$ approximately balance with respect to charge.

Some calcite precipitation apparently occurred when the cores were warmed during recovery, because the in situ samples have higher $\mathrm{Ca}$ and alkalinity than the squeezed samples (Fig. 2). Similarly, the difference between the in situ prime and overflow aliquots from 96 and 146 meters suggests that some calcite precipitated from the prime aliquot for these two samples. Precipitation is less likely to occur in the overflow aliquot because it is diluted in situ immediately on collection.

Below a depth of 100 meters, the reversed trends are less linear than the trends above 100 meters. Nonlinearity results either from the presence of additional reaction zones or from changes in the diffusive properties of the sediments. For sulfate, alkalinity, and $\mathrm{Ca}$, the profiles can be divided into three linear segments between the extrema at 100 meters and the sediment/basement contact, with changes in slope at 170 and 210 meters (Fig. 2). Ammonia likewise shows the change in slope at 210 meters, which corresponds to the diagenetic change from unconsolidated ooze to chalk.

These changes in slope are minor features of the overall reversed trends, however. The fact that the trends continue to basement indicates that for the sediment pore waters, the basement contact represents a source of sulfate and $\mathrm{Ca}$ and a sink for alkalinity, $\mathrm{Mg}$, and $\mathrm{NH}_{3}$. Because sulfate minerals are absent in the sediments and absent or extremely scarce in the upper 900 meters of the basement, the source of sulfate at the basement contact must be the basement pore water. The composition of this water is apparently close to that of unaltered seawater for these five species, as indicated by the composition of the basal sediment pore water.

Other species that display maxima or minima in the sediment column but reverse and trend toward seawater concentrations near basement are $\mathrm{K}, \mathrm{Li}$, and $\mathrm{Sr}$ (Fig. 3). 
Table 2. Composition of sediment pore water and surface seawater from Site 501/504.

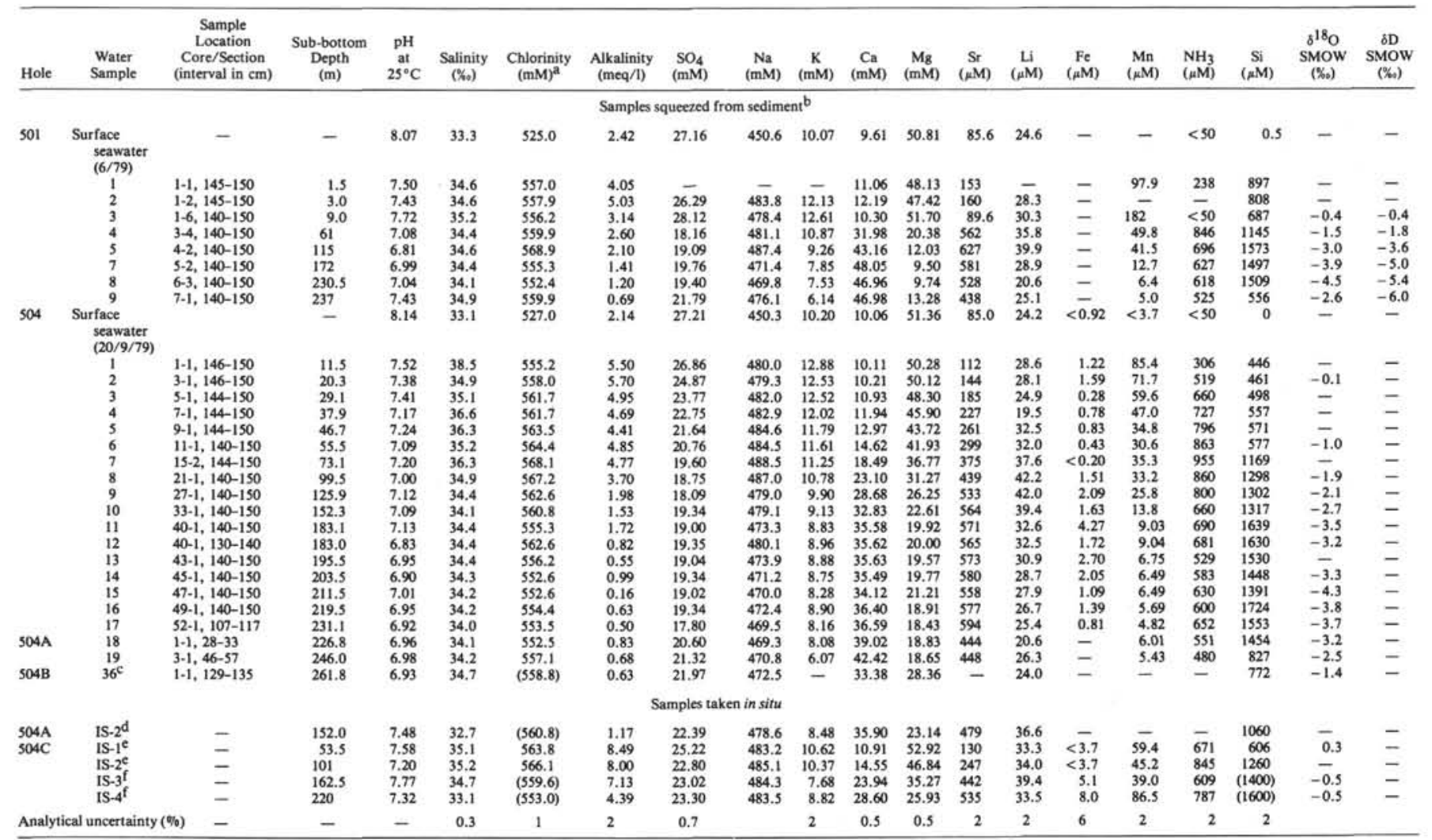

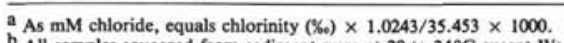

b All samples squeezed from sediment were at 20 to $24^{\circ} \mathrm{C}$ except Water Sample $504 \mathrm{~B}-36$ (which was at $6^{\circ} \mathrm{C}$ ).

C Water Sample 504B-36 was obtained by squeezing at $6^{\circ} \mathrm{C} 8$ days after the core was taken. Some evaporation occurred during that time. All values in the table except pH and $\delta^{18} \mathrm{O}$ have been corrected from the measured

chlorinity of $602.5 \mathrm{mM}(20.85 \%)$ to that estimated for the original sample (in parentheses in the table).
$\mathrm{IS}$ denotes in situ sample taken with the Barnes tool. Water Sample s04A-IS-2 consisted of a diluted overflow aliquot only; all values for it in the table except pH and ${ }^{18} \mathrm{O}$ have been corrected from the measured chlorinity of $602.5 \mathrm{mM}(20.85 \%)$ to that estimated for the original sample.
Data for $\mathrm{pH}$, salinity, chlorinity, alkalinity, $\mathrm{Ca}, \mathrm{Mg}, \mathrm{Mn}, \mathrm{NH}_{3}$, a

$f \mathrm{Data}$ for $\mathrm{pH}$ and $\delta^{18} \mathrm{O}$ are from the prime aliquot, which was contaminated with seawater during recovery. Other values were calculated from data for the overflow aliquot by modeling it as a mixture of pore water, surface seawater, and distilled water, assuming that the pore water had values for chlorinity and Si as given in the table (in parentheses).

Table 3. Composition of sediment pore water and surface seawater from Hole 505.

\begin{tabular}{|c|c|c|c|c|c|c|c|c|c|c|c|c|c|c|c|c|c|c|}
\hline Water Sample & $\begin{array}{c}\text { Sample } \\
\text { Location } \\
\text { Core/Section } \\
\text { (interval in } \mathrm{cm} \text { ) }\end{array}$ & $\begin{array}{l}\text { Sub-bottom } \\
\text { Depth } \\
\text { (m) }\end{array}$ & $\begin{array}{c}\mathrm{pH} \\
\text { at } \\
25^{\circ} \mathrm{C}\end{array}$ & $\begin{array}{c}\text { Salinity } \\
(\%)\end{array}$ & $\begin{array}{l}\text { Chlorinity } \\
(\mathrm{mM})^{\mathrm{a}}\end{array}$ & $\begin{array}{l}\text { Alkalinity } \\
\text { (meq/I) }\end{array}$ & $\begin{array}{c}\mathrm{SO}_{4} \\
(\mathrm{mM})\end{array}$ & $\underset{(\mathrm{mM})}{\mathrm{Na}}$ & $\underset{(\mathrm{mM})}{\mathrm{K}}$ & $\underset{(\mathrm{mM})}{\mathrm{Ca}}$ & $\underset{(\mathrm{mM})}{\mathrm{Mg}}$ & $\underset{(\mu \mathrm{M})}{\mathrm{Sr}}$ & $\underset{(\mu \mathrm{M})}{\mathrm{Li}}$ & $\begin{array}{c}\mathrm{Fe} \\
(\mu \mathrm{M})\end{array}$ & $\begin{array}{c}\mathrm{Mn} \\
(\mu \mathrm{M})\end{array}$ & $\begin{array}{l}\mathrm{NH}_{3} \\
(\mu \mathrm{M})\end{array}$ & $\underset{(\mu \mathrm{M})}{\mathrm{Si}}$ & $\begin{array}{c}\delta^{18} \mathrm{O} \\
\text { SMOW } \\
(\%)\end{array}$ \\
\hline \multicolumn{19}{|c|}{ Samples squeezed from sediments ${ }^{b}$} \\
\hline $\begin{array}{c}\text { Surface seawater } \\
(29 / 9 / 79)\end{array}$ & - & - & 8.05 & 33.6 & 532.2 & 1.93 & 27.55 & 454.8 & 10.25 & 10.19 & 51.82 & 85.1 & 24.1 & $<1.1$ & $<1.9$ & $<10$ & 4.3 & - \\
\hline 20 & $2-1,144-150$ & 2.0 & 7.71 & 34.6 & 552.8 & 3.04 & 28.50 & 474.3 & 12.26 & 10.23 & 52.67 & 85.4 & 28.0 & 5.30 & 105 & $<50$ & 548 & - \\
\hline 21 & $2-3,144-150$ & 5.0 & 7.64 & 34.6 & 557.4 & 4.27 & 27.86 & 478.6 & 12.37 & 9.88 & 53.02 & 83.9 & 26.7 & 1.20 & 103 & 203 & 687 & - \\
\hline 22 & $2-5,144-150$ & 8.0 & 7.53 & 34.4 & 558.3 & 3.98 & 27.93 & 479.6 & 12.12 & 9.91 & 52.99 & 89.2 & 26.5 & 1.96 & 92.9 & 186 & 674 & 0.0 \\
\hline 23 & $3-3,140-150$ & 14.5 & 7.40 & 34.6 & 561.1 & 6.85 & 25.99 & 481.2 & 12.11 & 8.40 & 54.44 & 88.8 & 27.9 & 3.95 & 80.5 & 496 & 704 & 0.2 \\
\hline 24 & $4-6,140-150$ & 28.5 & 7.29 & 34.4 & 562.9 & 8.93 & 23.35 & 484.2 & 12.20 & 6.20 & 54.32 & 87.2 & 26.5 & 1.71 & 39.7 & 786 & 758 & 0.3 \\
\hline 25 & $5-3,140-150$ & 33.5 & 7.29 & 34.6 & 561.1 & 9.41 & 22.83 & 482.9 & 12.41 & 5.95 & 53.90 & 86.6 & 27.4 & 2.22 & 36.6 & 842 & 746 & 0.0 \\
\hline 26 & $6-3,0-10$ & 41.6 & 7.27 & 34.4 & 562.0 & 8.38 & 23.72 & 484.2 & 12.09 & 6.21 & 54.00 & 89.3 & 26.9 & 2.65 & 39.8 & 805 & 755 & -0.2 \\
\hline 27 & $9-2,140-150$ & 70.0 & 7.29 & 34.2 & 562.9 & 13.26 & 18.96 & 484.0 & 11.91 & 3.74 & 54.57 & 83.8 & 24.2 & 1.98 & 17.7 & 1371 & 784 & - \\
\hline 28 & $11-4,140-150$ & 101.5 & 7.42 & 34.2 & 564.8 & 15.92 & 17.13 & 486.4 & 11.52 & 3.62 & 54.02 & 93.5 & 22.7 & 1.78 & 35.6 & 1504 & 822 & - \\
\hline 29 & $14-4,140-150$ & 130.0 & 7.21 & 34.2 & 562.9 & 13.19 & 17.87 & 482.0 & 11.37 & 3.63 & 54.57 & 98.1 & 21.9 & 2.96 & 16.3 & 1774 & 775 & -0.1 \\
\hline 30 & $17-5,140-150$ & 169.5 & 7.19 & 34.2 & 566.6 & 10.31 & 18.77 & 485.2 & 11.44 & 4.21 & 53.92 & 108 & 22.3 & 2.71 & 9.60 & 1281 & 837 & - \\
\hline 31 & $20-5,140-150$ & 198.0 & 7.12 & 34.4 & 560.2 & 7.58 & 21.44 & 480.3 & 11.07 & 5.78 & 53.25 & 113 & 19.5 & 1.13 & 7.31 & 886 & 814 & - \\
\hline 32 & $21-7,140-150$ & 210.5 & 7.26 & 35.0 & 562.0 & 6.19 & 22.36 & 480.2 & 11.15 & 6.51 & 53.79 & 107 & 19.2 & 2.16 & 6.55 & 724 & 799 & -0.3 \\
\hline 33 & $22-5,140-150$ & 217.0 & 7.25 & 34.5 & 564.8 & 5.06 & 23.80 & 483.0 & 11.60 & 7.14 & 53.87 & 107 & 20.4 & 2.09 & 5.18 & 587 & 768 & - \\
\hline 34 & $23-5,140-150$ & 226.5 & 7.30 & 35.2 & $\$ 63.8$ & 3.85 & 25.61 & 483.0 & 11.67 & 8.32 & 53.49 & 98.3 & 21.3 & 1.03 & 4.32 & 334 & 786 & - \\
\hline $35^{c}$ & $24-2,140-150$ & 231.5 & 7.48 & 34.2 & 553.3 & 1.22 & 26.54 & 471.8 & 12.53 & 8.39 & 53.07 & 83.3 & 22.9 & 1.11 & 9.51 & 142 & 635 & -0.2 \\
\hline \multicolumn{19}{|c|}{ Samples taken in situ } \\
\hline IS-1, prime & - & 95.5 & 8.08 & 34.1 & 561.1 & 16.78 & - & - & - & 3.97 & 55.95 & - & - & - & 26.5 & 1250 & - & - \\
\hline IS-1, overflow ${ }^{d}$ & - & - & - & - & $(172.0)$ & (18.54) & 23.23 & 492.5 & 10.41 & 4.85 & 55.95 & 82.0 & 30.5 & - & 22.7 & 878 & 250 & - \\
\hline IS-2, prime & - & 145.5 & 8.03 & 34.1 & 556.5 & 13.33 & - & - & - & 4.63 & 54.95 & - & - & - & 22.3 & 1087 & - & - \\
\hline IS-2, overflow & - & - & - & - & $(367.0)$ & $(14.13)$ & 20.64 & 480.2 & 10.27 & 5.03 & 54.95 & 105 & 23.8 & - & 18.7 & 544 & 584 & - \\
\hline IS- $3^{\mathrm{e}}$ & - & 183 & 8.10 & 34.2 & 555.5 & 10.68 & 20.93 & 478.0 & 10.25 & 5.99 & 53.29 & 115 & 23.7 & - & 17.5 & 928 & 670 & - \\
\hline IS $-4^{e}$ & - & 211 & 7.83 & 34.2 & 556.5 & 6.64 & 24.92 & 478.5 & 10.69 & 8.12 & 53.32 & 114 & 22.3 & - & 11.7 & 603 & 651 & - \\
\hline
\end{tabular}

As $\mathrm{mM}$ chloride, equals chlorinity $(\%) \times 1.0243 / 35.453 \times 1000$

All samples squeezed from sediment were at 6.8 to $10.5^{\circ} \mathrm{C}$ except Water Sample $505-35$ (which was at $14^{\circ} \mathrm{C}$ ).

c Water Sample 505-35 was squeezed 6 days after collection. The core interval appeared highly disturbed and was probably contaminated by drilling fluid (surface seawater).

Data have been normalized to the chlorinity of the prime aliquot, except for chlorinity and alkalinity (in parentheses). Alkalinity was calculated from the difference in Ca between the prime and normalized overflow aliquots.

Data for $\mathrm{pH}$, salinity, chlorinity, alkalinity, $\mathrm{Ca}, \mathrm{Mg}, \mathrm{Mn}$, and $\mathrm{NH}_{3}$ are from the prime aliquot. Other data are from the overflow aliquot normalized to the chlorinity of the prime aliquot. $\mathrm{Mg}$ is identical in 


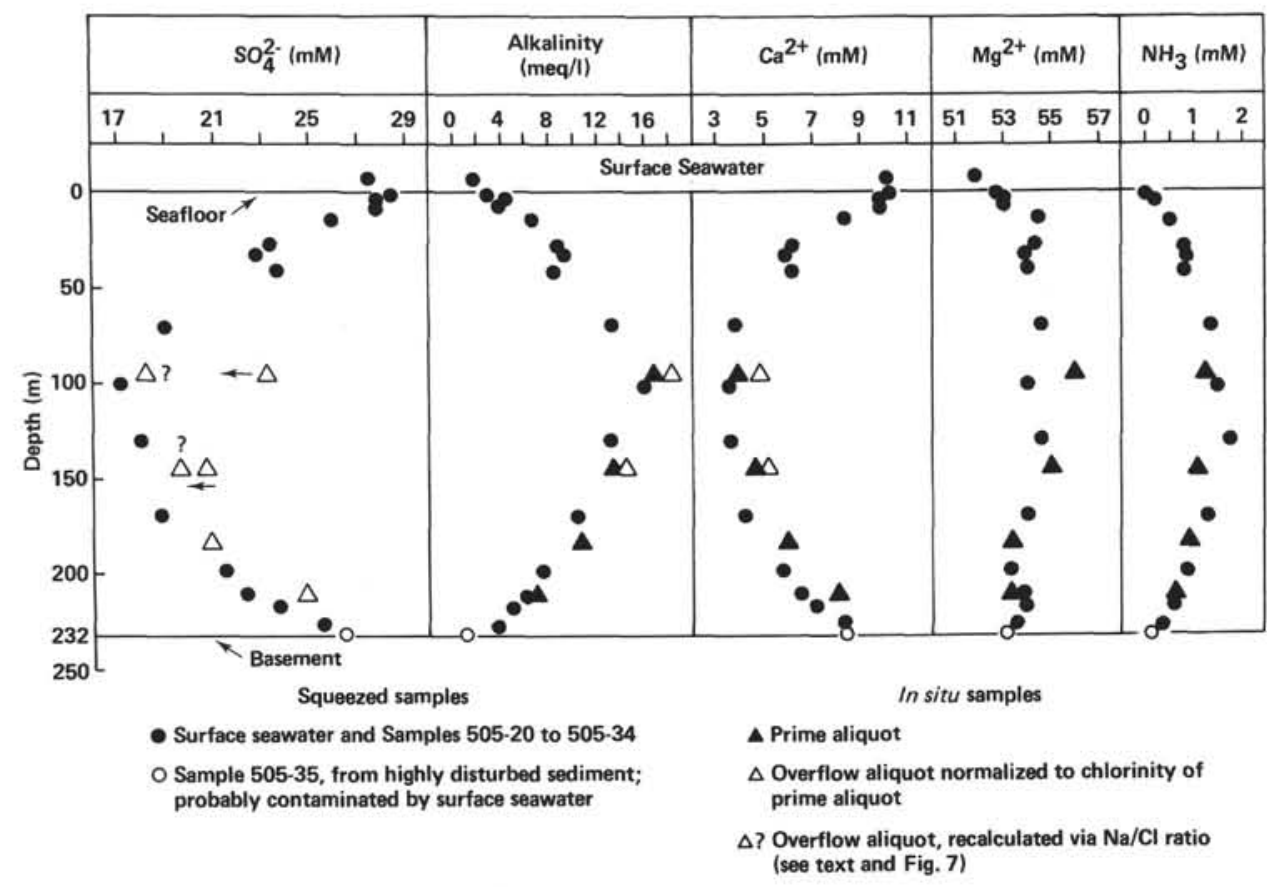

Figure 2. Composition of sediment pore waters in Hole 505.

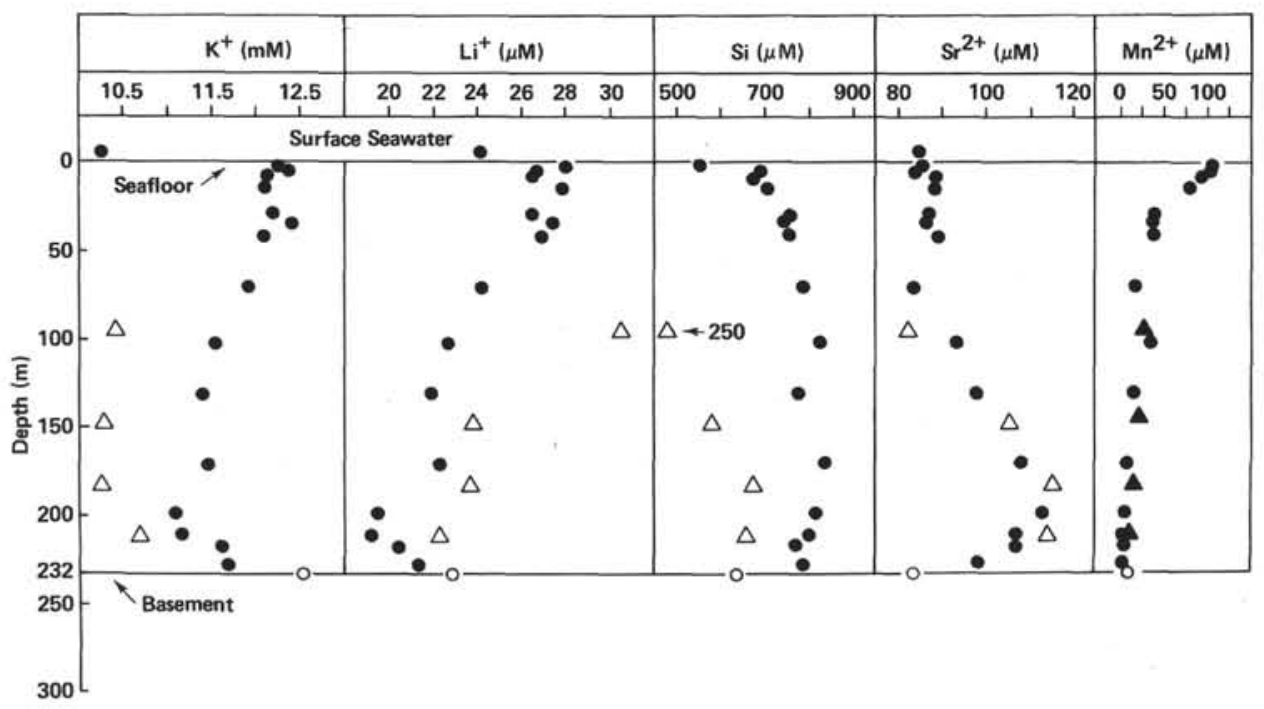

Figure 3. Composition of sediment pore waters in Hole 505. See Figure 2 for key.

The major trend reversal for these species occurs at or near the ooze-chalk boundary at 210 meters. The $\mathrm{K}$ data show a large temperature of squeezing effect, especially in the upper 50 meters, where the temperature discrepancy was largest, but the $\mathrm{K} / \mathrm{Cl}$ ratios of the in situ samples indicate that $\mathrm{K}$ is depleted in the sediment column and returns to seawater concentrations near basement. $\mathrm{Li}$ is similarly depleted in the sediment pore waters and may or may not still be depleted at the basement contact. $\mathrm{Sr}$ is slightly depleted to 100 meters and enriched below that depth to a maximum at 200 meters, but it decreases again toward seawater values near basement.

Chemical species that do not exhibit prominent trend reversals are $\mathrm{Mn}, \mathrm{Fe}, \mathrm{Si}, \mathrm{Na}, \mathrm{Cl}$, and $\delta^{18} \mathrm{O}$. Mn (Fig. 3) shows a maximum in near-surface sediments, drops sharply at depths to 29 meters, and declines gradually at depths below that to basement. Fe shows a similar pattern but with much more scatter. Si (Fig. 3), Na, and $\mathrm{Cl}$ (Fig. 4) increase sharply in the upper 25 meters to a value that remains largely constant below that depth. $\delta^{18} \mathrm{O}$ varies within a narrow range from 0 to 0.3 in the upper 30 meters and from 0 to -0.3 at depths from 30 meters to basement.

A plot of the $\mathrm{Na} / \mathrm{Cl}$ ratio (Fig. 4) shows that two of the in situ samples, especially that from the most active zone of bacterial sulfate reduction at a depth of 100 meters, show anomalously high $\mathrm{Na} / \mathrm{Cl}$ ratios. Since $\mathrm{Na}$ was calculated from charge balance, the anomalous values 


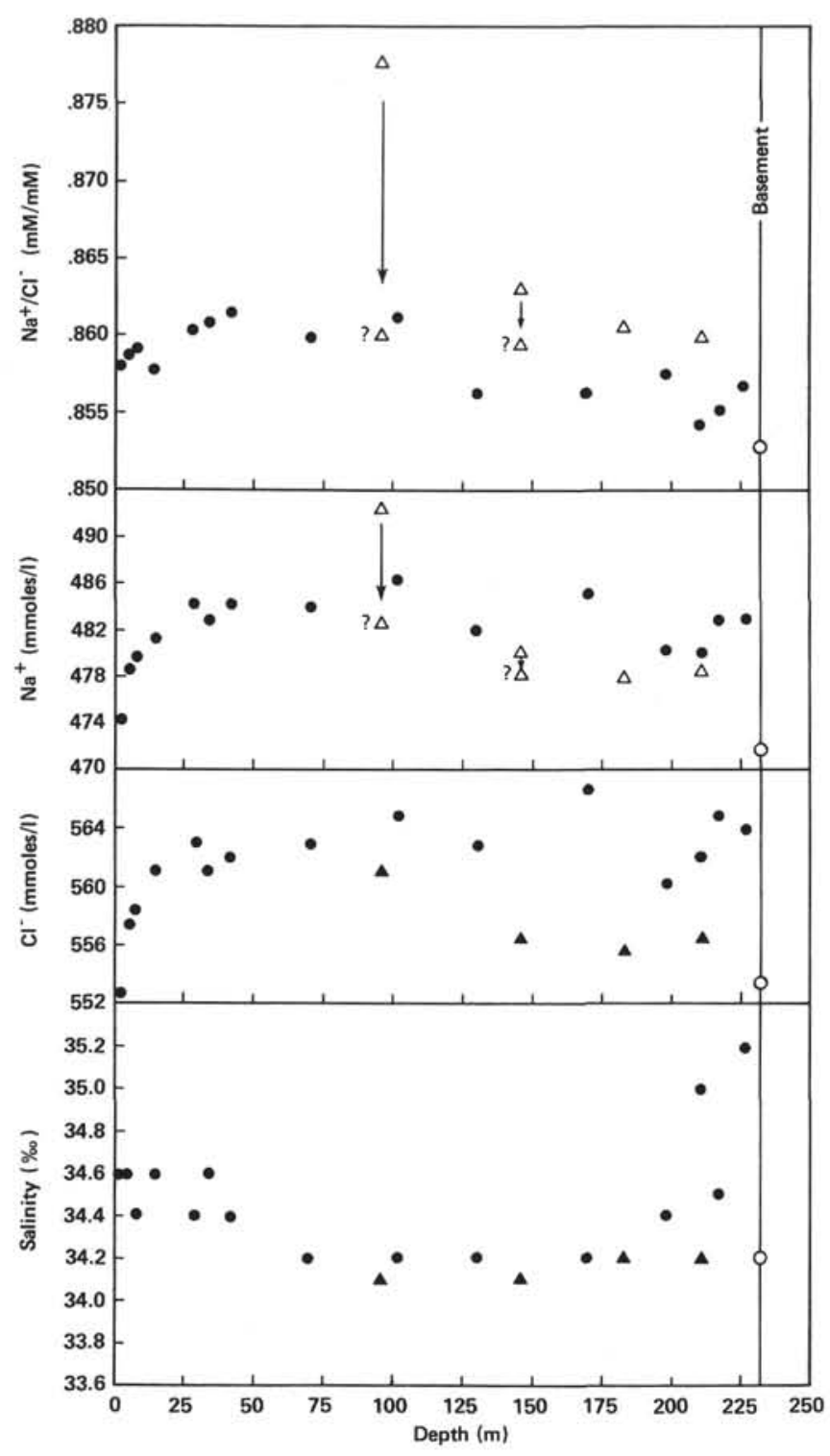

Figure 4. Composition of sediment pore waters in Hole 505. See Figure 2 for key. Values for $\mathrm{Na}$ were calculated from charge balance; two in situ samples (open triangles) have anomalously high $\mathrm{Na}$ and $\mathrm{Na} / \mathrm{Cl}$ because of spuriously high sulfate measured in the overflow aliquots, resulting from oxidation of $\mathrm{H}_{2} \mathrm{~S}$. See text and sulfate values in Figure 2 for comparison.

are believed to result from an overestimate of some measured anion. Comparison with Figure 2 suggests that this anion is sulfate, which for the in situ samples was measured in the diluted overflow aliquot. Apparently some of the abundant $\mathrm{H}_{2} \mathrm{~S}$ in these samples was oxidized to sulfate prior to analysis. This sulfate would have been balanced by $\mathrm{H}^{+}$initially, which would combine with $\mathrm{HCO}_{3}^{-}$and be lost as $\mathrm{CO}_{2}$. The anomalously low alkalinity was not measured, because this species was analyzed much earlier and only on the prime aliquot. The resulting spurious charge balance showed up only in the calculated values for $\mathrm{Na}$. The shape of the $\mathrm{Na} / \mathrm{Cl}$ profile in Figure 4, with a maximum at the $\mathrm{H}_{2} \mathrm{~S}-$ rich intermediate depths, implies that a small amount of $\mathrm{H}_{2} \mathrm{~S}$ may have been oxidized in the squeezed samples as well. This case demonstrates the usefulness of analyzing both aliquots from the in situ sampler.

In summary, the sediment pore water chemistry at Site $\mathbf{5 0 5}$ is dominated by the effects of bacterial sulfate reduction and by diffusion between this zone of intense reaction and the upper and lower boundaries of the sediment column, both of which fix the pore water composition near that of unaltered seawater. The bacterial reaction zone is most intense at an intermediate depth of 100 meters and has a large effect on sulfate, alkalinity, $\mathrm{NH}_{3}$, and $\mathrm{Ca}$ and a small effect on $\mathrm{Mg}$ and $\mathrm{Sr}$. A second reaction zone that affects these species as well as $\mathrm{K}$ and $\mathrm{Li}$ is probably present at the ooze-chalk boundary 22 meters above basement. The fact that the sediment pore water composition near the basement contact closely approaches that of seawater implies that the cool seawater circulating through basement is largely unaltered. Apparently the flow rate of seawater through basement at this site is rapid relative to its rate of reaction with basement basalts at the low prevailing temperature, which is only $9^{\circ} \mathrm{C}$ at the basement contact.

\section{Site 501/504}

Five holes were drilled at Site 501/504 roughly along an east-west line 500 meters long (Fig. 5). The most unusual feature of the pore water profiles from this site is the pronounced variation in solution composition that occurs laterally over this distance.

Figure 6 shows the lateral and vertical variations in alkalinity, $\mathrm{Ca}$, and $\mathrm{Mg}$. The vertical variations are similar to those observed in many DSDP holes and are opposite to those at Site 505 for $\mathrm{Ca}$ and $\mathrm{Mg}$; Ca increases and $\mathrm{Mg}$ decreases with depth on nearly a mole-for-mole basis. Alkalinity exhibits a maximum that is smaller and much shallower than at Site 505 and then decreases to even lower values near basement. For all three chemical species, the concentration at a given depth varies regularly over the 300 meters from west to east between Hole 501 and Hole 504C, indicating the presence of a continuous lateral gradient over that distance. This is shown for $\mathrm{Ca}$ in Figure 7.

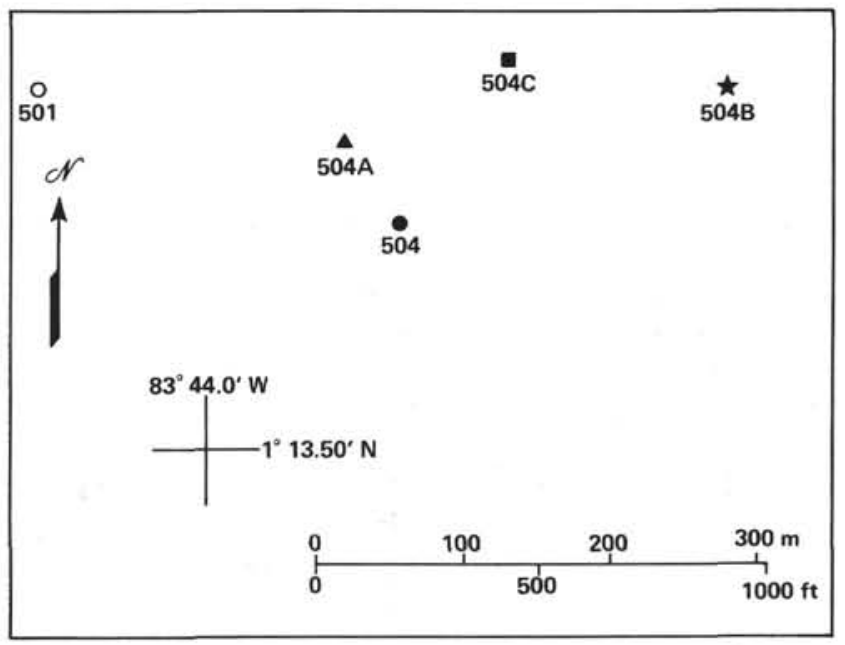

Figure 5. Location of the five holes at Site 501/504. 


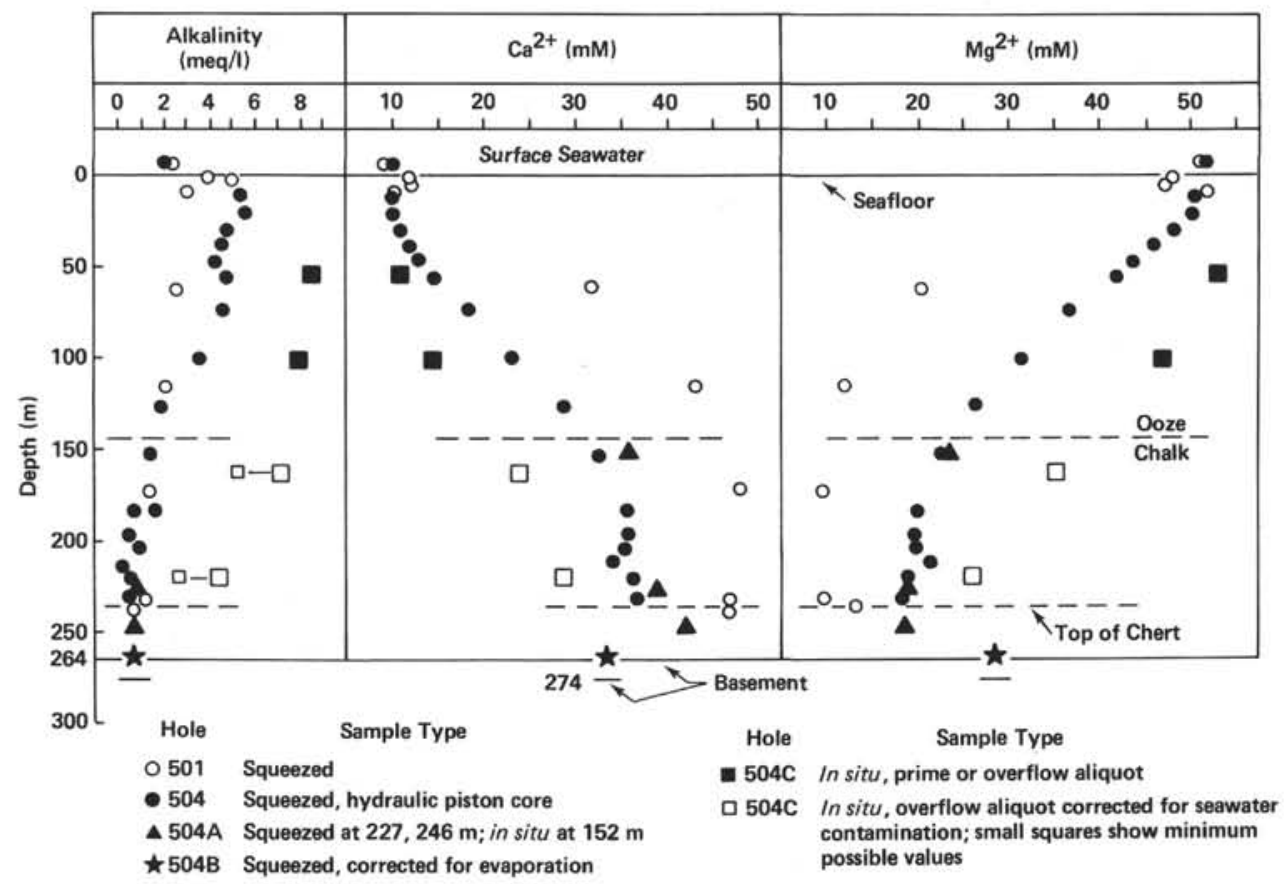

Figure 6. Composition of sediment pore waters from Site 501/504.

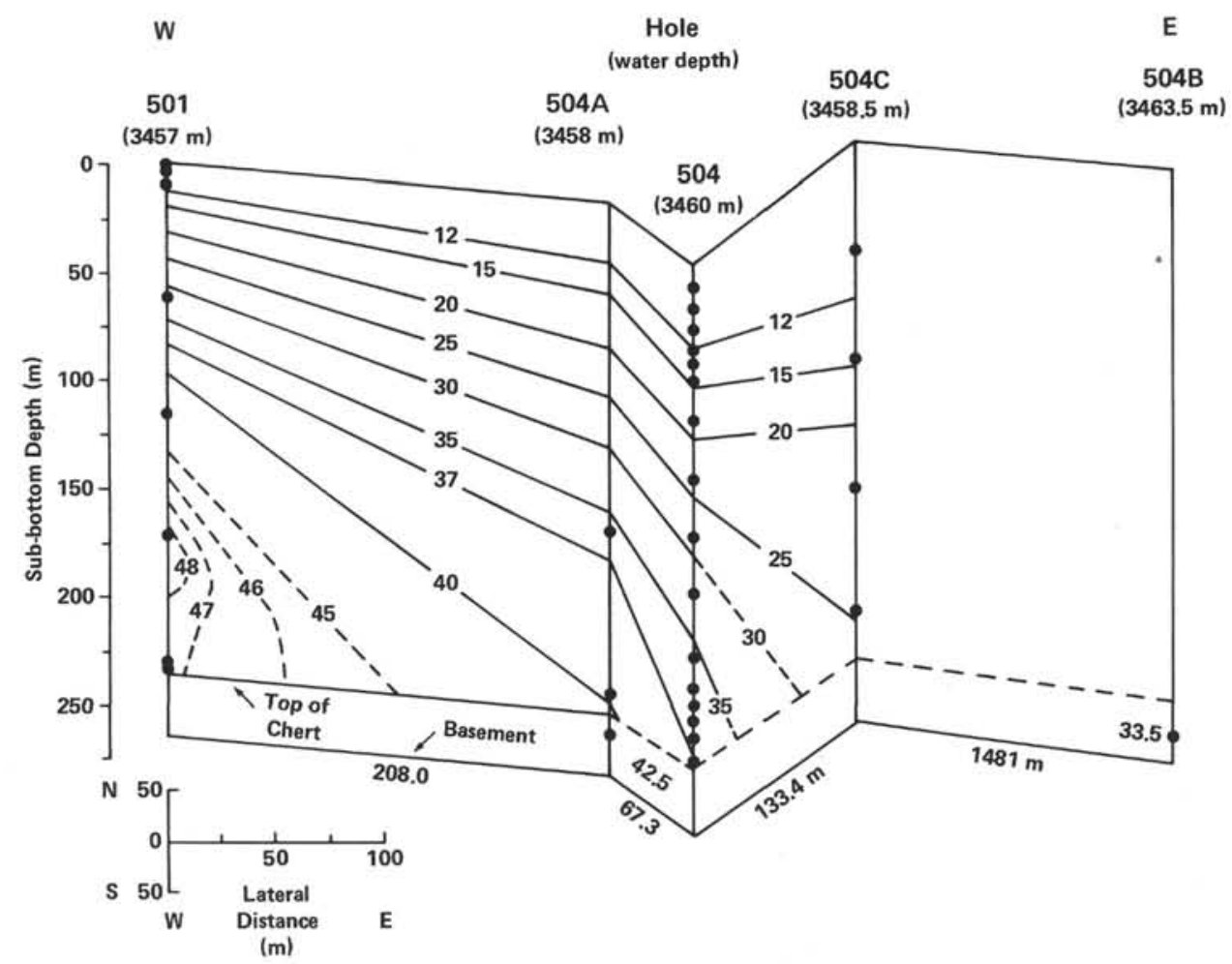

Figure 7. Three-dimensional fence diagram depicting the spatial relationships of the five holes drilled at Site 501/504 and the concentration of $\mathrm{Ca}^{2+}$ with depth in the sediment pore waters. The $\mathrm{Ca}^{2+}$ concentration is contoured in mmoles/liter. Contours are based on samples, shown as closed circles, from five holes situated approximately along at east-west line over a distance of 464 meters. View is straight north; horizontal and vertical scales are equal, except that the diagram is foreshortened north to south by a factor of 2 . 
Other species that show obvious lateral variations are sulfate and $\mathrm{Sr}$ (Fig. 8) and $\delta^{18} \mathrm{O}$ (Fig. 9). For these species the lateral variation is apparently less regular than for $\mathrm{Ca}$, because the order of the two intermediate holes (Holes 504 and 504A) is reversed. Whether $\delta \mathrm{D}$ (Fig. 9) shows lateral gradients cannot be determined, because this species was only analyzed in Hole 501 .

The origin of the lateral gradients in sediment pore water composition at this site cannot yet be determined with certainty, but it is clearly related in some way to the origin of the vertical gradients. The decrease in sulfate with depth to a nearly constant value below 100 meters (Fig. 8) is almost certainly due to bacterial activity, as are the shallow maxima in alkalinity (Fig. 6) and $\mathrm{NH}_{3}$ (Fig. 10). The lateral gradient in sulfate concentration over the depth interval from 50 to 100 meters implies that the sulfate-reducing bacteria in Hole 504 are more active at that depth than they are in Hole $504 \mathrm{C}$ and less active than they are in Hole 501. This may result from a lateral difference in temperature or sediment composition, but the evidence at hand (Beiersdorf and Natland, this volume) indicates that such differences must be very small.

In any case, bacterial sulfate reduction is not the dominant influence on sediment pore water chemistry at this site, as it is at Site 505. This can be seen in the pro-

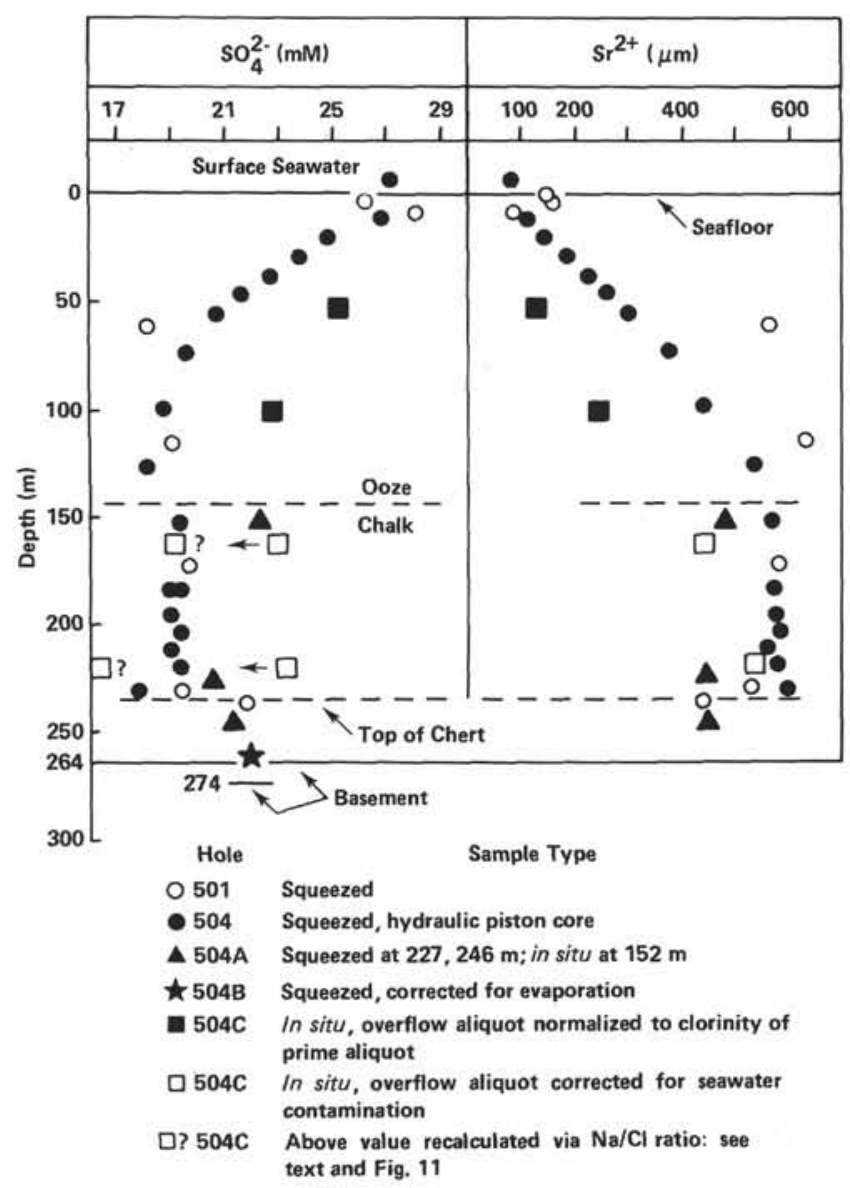

Figure 8. Sulfate and $\mathrm{Sr}$ in sediment pore waters from Site 501/504. files for alkalinity and $\mathrm{Ca}$ (Fig. 6). Alkalinity reaches the largest maximum in Hole 504C, the hole with the smallest sulfate decrease; at a depth of 50 meters, the alkalinity gain $(6 \mathrm{meq} / \mathrm{l})$ more than balances the sulfate loss $(4 \mathrm{meq} / \mathrm{l})$. For the other holes, however, the sulfate loss far exceeds the alkalinity gain at this depth by the same amount that the $\mathrm{Mg}$ loss exceeds the $\mathrm{Ca}$ gain. Thus, the large amount of alkalinity that must have been produced by sulfate reduction via Reaction 1 has apparently been consumed (along with $\mathrm{Ca}$ ) via Reaction 2 ( $\mathrm{CaCO}_{3}$ precipitation). The $\mathrm{Ca}$ concentration has nevertheless increased, while $\mathrm{Mg}$ has decreased. Except for the upper 50 meters in Hole $504 \mathrm{C}$, therefore, the reactions that dominate the pore water chemistry are those that have produced $\mathrm{Ca}$ and consumed $\mathrm{Mg}$.

The pattern of $\mathrm{Ca}$ enrichment accompanied by $\mathrm{Mg}$ and ${ }^{18} \mathrm{O}$ depletion observed at this site is common in DSDP holes. It has been convincingly attributed in general to the alteration of basement basalts beneath the sediment column (Lawrence et al., 1975; Lawrence and Gieskes, 1981; and McDuff, 1981). This explanation almost certainly applies here, because the sediments contain 10 to $25 \%$ clay and $<1 \%$ volcanic glass that is rhyolitic and not obviously altered (Beiersdorf and Natland, this volume). These concentrations are too small to account for the depletions in ${ }^{18} \mathrm{O}$ and $\mathrm{Mg}$ by the alteration of the silicate fraction in the sediments.

If the vertical gradients in $\mathrm{Ca}, \mathrm{Mg}$, and $\delta^{18} \mathrm{O}$ originate mainly through the reaction of seawater-derived solutions with the basement basalts, it follows that the lateral gradients in these species also originate from basement. Either the basement pore waters vary laterally in composition or, if they are uniform, the effect of their composition propagates nonuniformly through the sediments by advection or diffusion or both.

The data in Figure 11 support the former hypothesis. The linear reduction in the $\mathrm{Na} / \mathrm{Cl}$ ratio of the sediment pore waters with increasing depth suggests that $\mathrm{Na}$ is being taken up by basalts that are undergoing alteration in the basement and that it is unreactive in the sediments. If the basement pore waters were laterally uniform in composition and the lateral gradients in $\mathrm{Ca}$ and $\mathrm{Mg}$ resulted from differential propagation of this uniform basement signal through the sediments, one would expect differential propagation of the Na-depletion signal as well. The $\mathrm{Na} / \mathrm{Cl}$ ratio, however, shows no lateral variation in the sediment pore waters. Thus, the most likely explanation is that the basement pore waters vary laterally in their amount of $\mathrm{Ca}$ enrichment and $\mathrm{Mg}$ depletion but have a constant $\mathrm{Na}$ and chloride concentration. These lateral gradients propagate upward through the sediment pore waters by diffusion and are modified secondarily by diagenetic reactions in the sediments.

The other alkali elements, $\mathrm{K}$ and $\mathrm{Li}$, like $\mathrm{Na}$, show no obvious lateral gradients (Fig. 12), although K may be lower in Hole 501 than in the other holes. $\mathrm{K}$ is spuriously high in the upper 100 meters because of the temperature of squeezing effect, but it definitely becomes more depleted in the lower sediment pore waters as the basement is approached. Both $\mathrm{K}$ and $\mathrm{Li}$ are affected by reactions in the sediments. The $\mathrm{K}$ concentration drops sharp- 


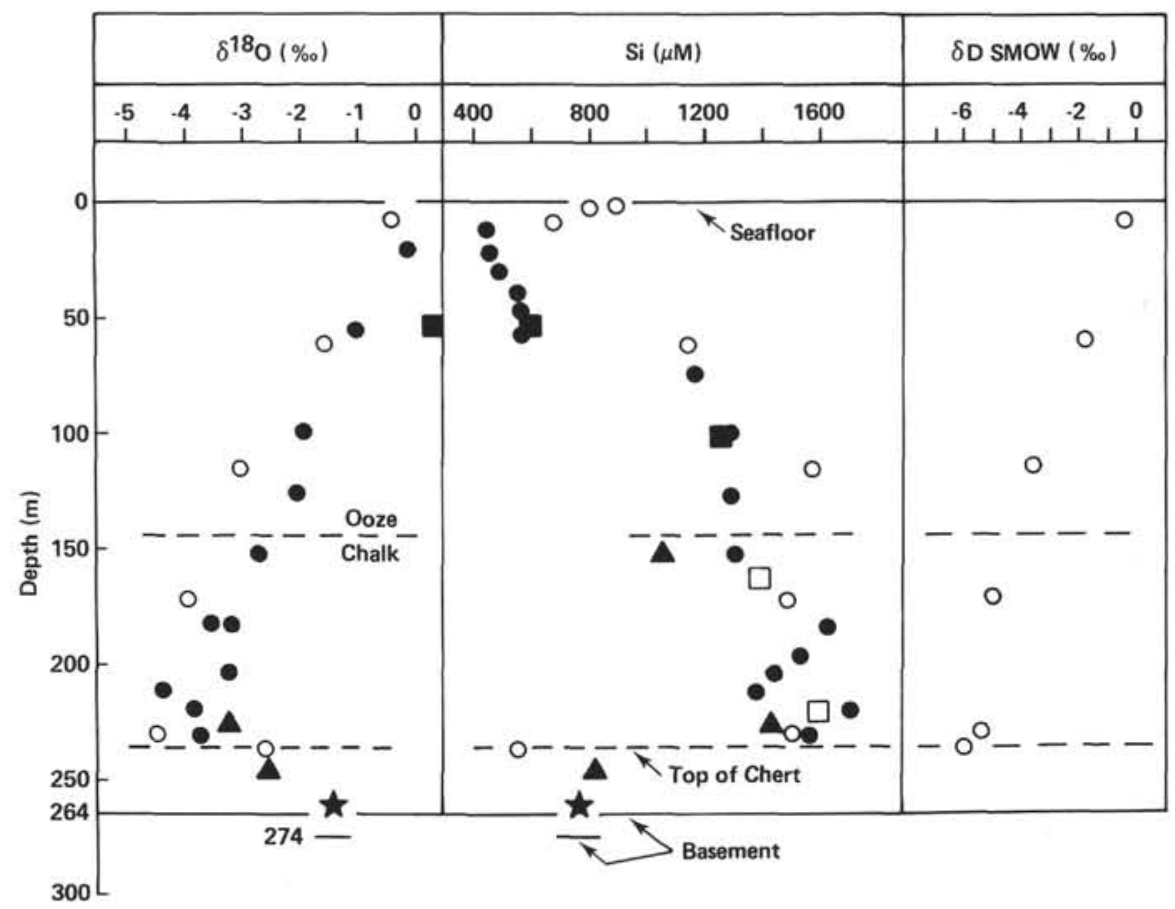

Figure 9. $\delta^{18} \mathrm{O}, \mathrm{Si}$, and $\delta \mathrm{D}$ in sediment pore waters from Site 501/504. See Figure 6 for key.

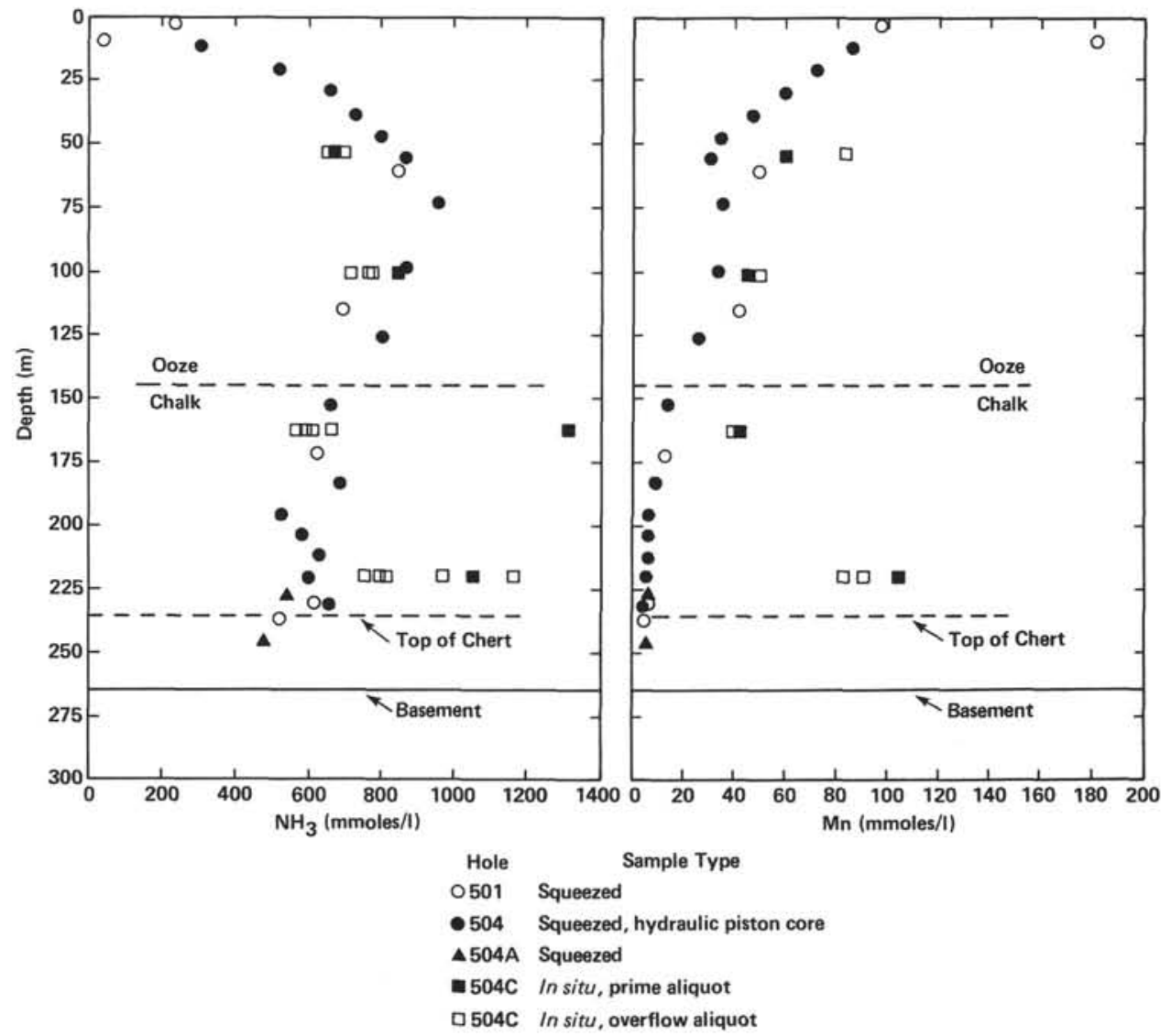

Figure 10. $\mathrm{NH}_{3}$ and $\mathrm{Mn}$ in sediment pore waters from Site 501/504. 


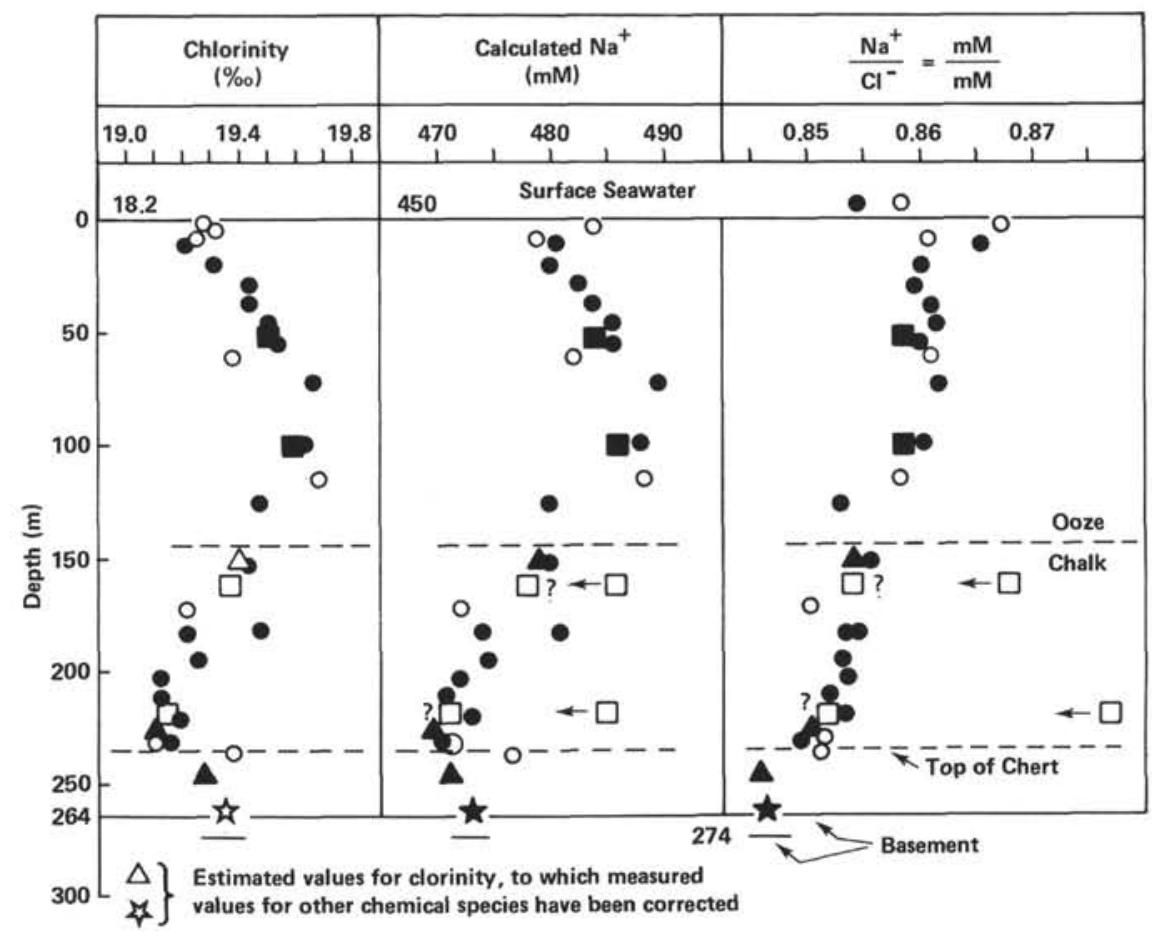

Figure 11. $\mathrm{Na}$ and $\mathrm{Cl}$ in sediment pore waters from Site 501/504. See Figure 8 for bulk of key. Values for $\mathrm{Na}$ were calculated via charge balance; two in situ samples that were contaminated with seawater (open squares) have anomalously high $\mathrm{Na}$ and $\mathrm{Na} / \mathrm{Cl}$, which may or may not be due to an overestimate of sulfate (see Fig. 8).

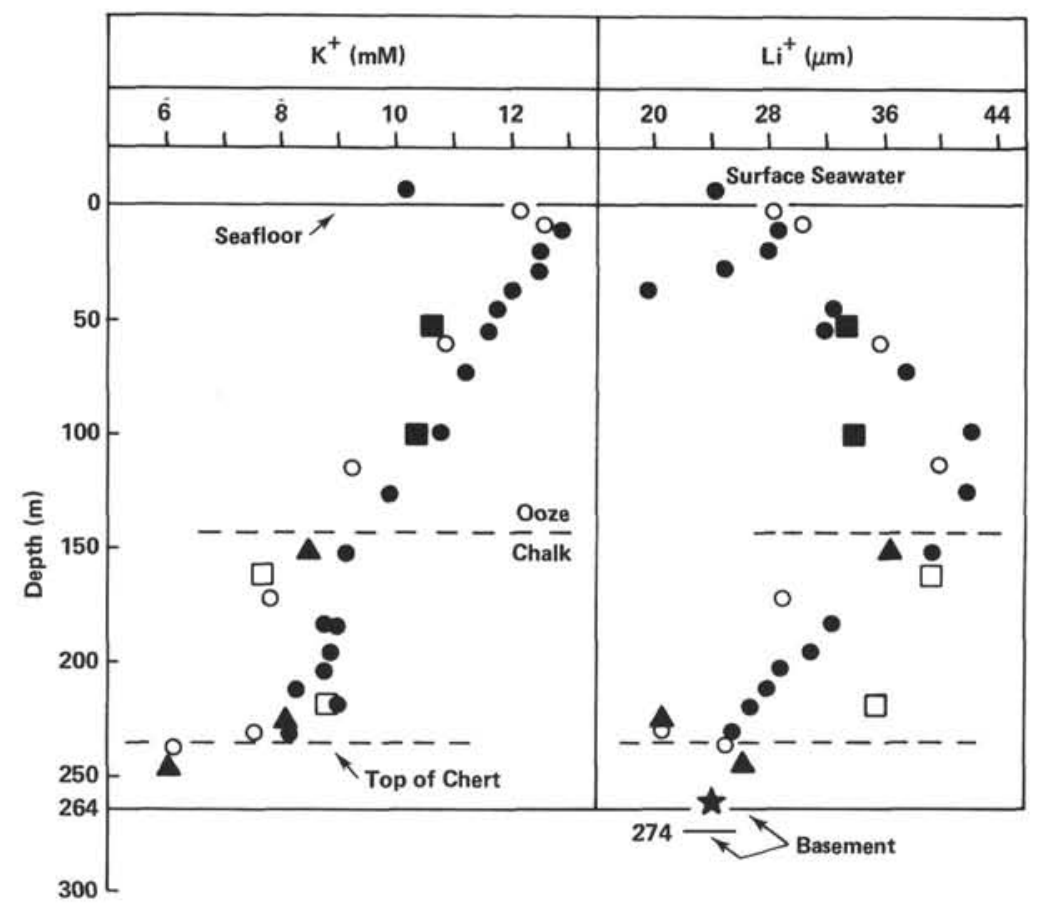

Figure 12. $\mathrm{K}$ and $\mathrm{Li}$ in sediment pore waters from Site 501/504. See Figure 6 for key,

ly at the top of the chert section. Li shows a complex pattern due to diagenetic reactions, with a strong sink at a depth of 38 meters and a source in the sediments near the ooze/chalk boundary at 143 meters. Below that depth it decreases toward basement.

The Mn profile (Fig. 10) is similar to that at Site 505 .
In summary, the sediment pore water profiles at Site $501 / 504$ are greatly affected by reactions in the basaltic basement, which is presently at temperatures of $59^{\circ} \mathrm{C}$ and higher. Lateral variations in sediment pore water chemistry exist for alkalinity, $\mathrm{Ca}, \mathrm{Mg}$, sulfate, $\mathrm{Sr}, \delta^{18} \mathrm{O}$, and possibly $\mathrm{K}$. These gradients apparently result large- 
ly from diffusive propagation upward through the sediments of similar lateral gradients in the composition of the basement pore waters. The basement waters are apparently enriched in $\mathrm{Ca}$ and depleted in $\mathrm{Mg}, \mathrm{Na}, \mathrm{K},{ }^{18} \mathrm{O}$, deuterium, sulfate, and alkalinity relative to seawater.

\section{THERMAL HISTORY OF THE CRUST AT SITE 501/504}

A most unusual feature of the sediment pore water profiles at Site $501 / 504$ is the reversal in the $\delta^{18} \mathrm{O}$ gradient with increasing depth (Fig. 9). This is the first time this feature has been seen in a DSDP hole. The reversal coincides with the lower diagenetic boundary at 235 meters between chalk above and a zone below in which limestone and chert are intercalated. At this same depth $\mathrm{Si}$ in the pore waters decreases sharply to a concentration approximately equal to chalcedony saturation at the in situ temperature of $56^{\circ} \mathrm{C}$ (Fig. 9). The $\delta^{18} \mathrm{O}$ of the carbonate fraction of the sediments also drops sharply, after decreasing by about $2 \%$ in the upper 235 meters (Table 4 and Fig. 13). The slight decrease in the upper sediments is reflected in the $\delta^{18} \mathrm{O}$ of the benthic foraminifera, which decreases by the same $2 \%_{0}$ from the depth at which $\mathrm{CaCO}_{3}$ overgrowths first appear $(153 \mathrm{~m})$ to the top of the chert (Table 5 and Fig. 14). These features of the carbonate isotopic chemistry have been observed at two other DSDP sites in the Panama Basin: Site 157 on the Carnegie Ridge and Site 158 on the Cocos Ridge (Keigwin, 1979). These sites share other features with Site 501/504, including high sedimentation rates, high heat flow, and similar lithologies, with chert present deeper in the sections.

The large ${ }^{18} \mathrm{O}$ depletions observed in the sediment pore waters at Site 501/504 have been attributed to the alteration of basement basalts, as discussed earlier. By making some fairly simple assumptions the diagenesis of the lowermost sediments can be shown to account for the reversal toward heavier values of $\delta^{18} \mathrm{O}$ in the pore waters and the sharp decrease in $\delta^{18} \mathrm{O}$ of the carbonate sediments that occur at a depth of 235 meters.

For this we used the model of Lawrence et al. (1976). In this model carbonate with an initial $\delta^{18} \mathrm{O}$ value of $31 \%$ (SMOW) is allowed to recrystallize in a pore fluid

Table 4. Oxygen isotope composition of the carbonate fraction of sediments from Hole 501.

\begin{tabular}{cccc}
\hline Sample & $\begin{array}{c}\text { Interval } \\
(\mathrm{cm})\end{array}$ & $\begin{array}{c}\text { Depth } \\
(\mathrm{m})\end{array}$ & $\begin{array}{c}\delta^{18} \mathrm{O} \\
\mathrm{SMOW} \\
(\%)\end{array}$ \\
\hline $501-1-3$ & $30-32$ & 3.3 & 30.9 \\
$3-3$ & $86-87$ & 58.9 & 31.1 \\
$4-3$ & $25-26$ & 115.4 & 30.6 \\
$5-3$ & $47-48$ & 172.6 & 29.5 \\
$6-3$ & $30-31$ & 229.4 & 29.7 \\
$7-1$ & $127-128$ & 236.9 & 28.2 \\
$8, \mathrm{CC}$ & - & 245.1 & 27.0 \\
$9-1$. & $10-11$ & 254.7 & 28.2 \\
$10-1$ & $4-6$ & 264.1 & 27.3 \\
\hline
\end{tabular}

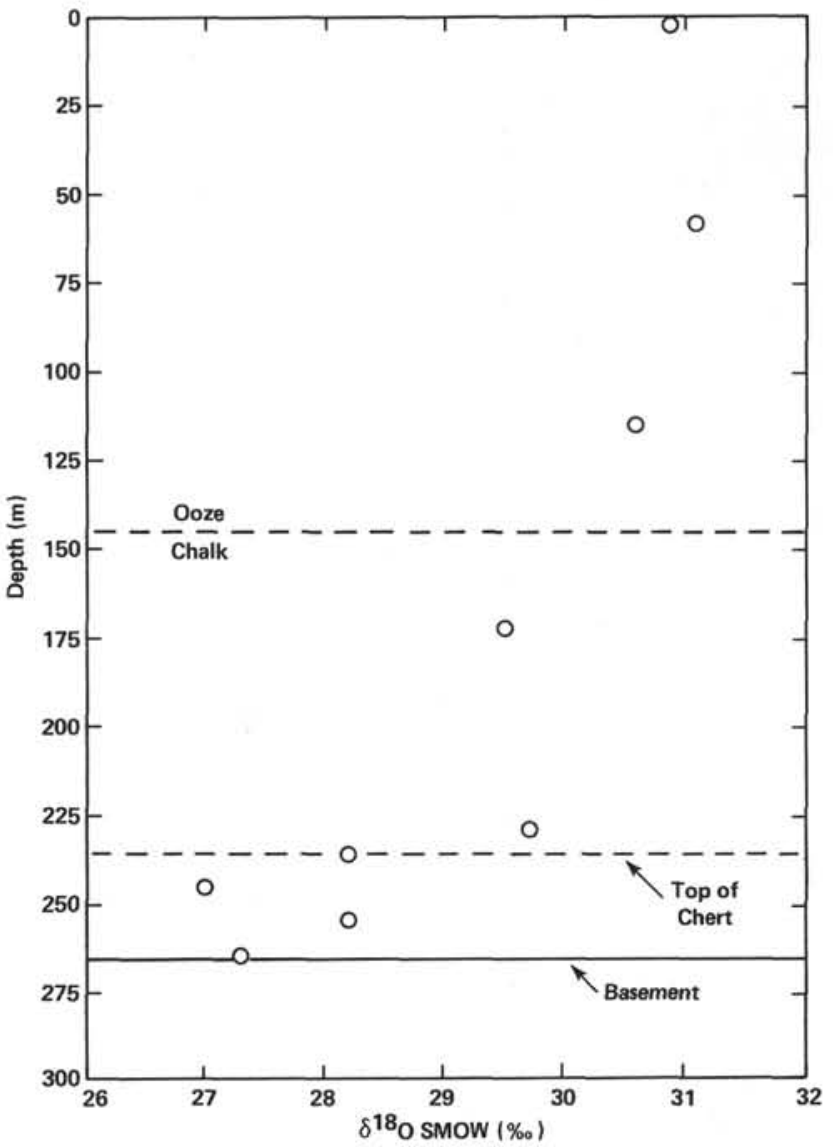

Figure 13. The $\delta^{18} \mathrm{O}$ of the carbonate fraction of the sediments from Hole 501.

Table 5. Stable isotope composition of Hole 504 benthic foraminifera.

\begin{tabular}{|c|c|c|c|c|c|}
\hline \multirow[b]{2}{*}{ Sample } & \multirow[b]{2}{*}{$\begin{array}{l}\text { Depth } \\
\text { (m) }\end{array}$} & \multicolumn{2}{|c|}{ Cibicidoides spp. } & \multicolumn{2}{|c|}{ Uvigerina spp. } \\
\hline & & $\begin{array}{c}\delta^{18} \text { O PDB } \\
(\%)\end{array}$ & $\begin{array}{c}{ }_{\delta^{13} C \text { PDB }}^{13} \\
(\%)\end{array}$ & $\begin{array}{c}\delta^{18} \text { O PDB } \\
(\%)\end{array}$ & $\begin{array}{c}\delta^{13} C_{(\%)} \text { PDB } \\
(\%)\end{array}$ \\
\hline $504-28, C C$ & 131.2 & - & - & 3.12 & -1.40 \\
\hline $29, \mathrm{CC}$ & 137.5 & 1.88 & -0.28 & - & - \\
\hline $30, \mathrm{CC}$ & 141.3 & 1.80 & -0.45 & - & - \\
\hline $31, \mathrm{CC}$ & 144.9 & - & - & 3.25 & -1.37 \\
\hline $32, \mathrm{CC}$ & 150.1 & 1.48 & -0.30 & - & - \\
\hline $33, \mathrm{CC}$ & 152.8 & - & - & 1.88 & -0.80 \\
\hline $34, \mathrm{CC}$ & 158.6 & - & - & 2.35 & -0.98 \\
\hline $35, \mathrm{CC}$ & 163.6 & 1.02 & -0.17 & - & - \\
\hline $36, \mathrm{CC}$ & 167.3 & 1.60 & -0.41 & - & - \\
\hline $37, \mathrm{CC}$ & 171.7 & 1.46 & -0.13 & - & - \\
\hline $38, \mathrm{CC}$ & 176.8 & - & - & 2.40 & -0.93 \\
\hline $39, \mathrm{CC}$ & 177.7 & - & - & 2.29 & -0.87 \\
\hline $40, \mathrm{CC}$ & 184.1 & 1.17 & +0.01 & & \\
\hline $41, \mathrm{CC}$ & 189.8 & - & - & 2.12 & -0.75 \\
\hline $42, \mathrm{CC}$ & 192.4 & - & - & 2.17 & -0.76 \\
\hline $43, \mathrm{CC}$ & 198.4 & 1.40 & -0.69 & - & - \\
\hline $44, \mathrm{CC}$ & 200.3 & - & - & 2.09 & -1.07 \\
\hline $45, \mathrm{CC}$ & 204.5 & - & - & 1.65 & -0.93 \\
\hline $46, \mathrm{CC}$ & 207.7 & - & - & 1.92 & -0.76 \\
\hline $47, \mathrm{CC}$ & 211.7 & - & - & 1.87 & -0.71 \\
\hline $48, \mathrm{CC}$ & 215.3 & - & - & 1.55 & -0.72 \\
\hline $49, \mathrm{CC}$ & 220.1 & 1.37 & -0.24 & - & - \\
\hline $50, \mathrm{CC}$ & 223.7 & - & - & 1.67 & -0.82 \\
\hline $51, \mathrm{CC}$ & 227.5 & - & - & 1.64 & -0.76 \\
\hline $52, \mathrm{CC}$ & 231.3 & - & - & 1.50 & -1.01 \\
\hline $53, \mathrm{CC}$ & 234.8 & 1.06 & -0.42 & - & - \\
\hline
\end{tabular}




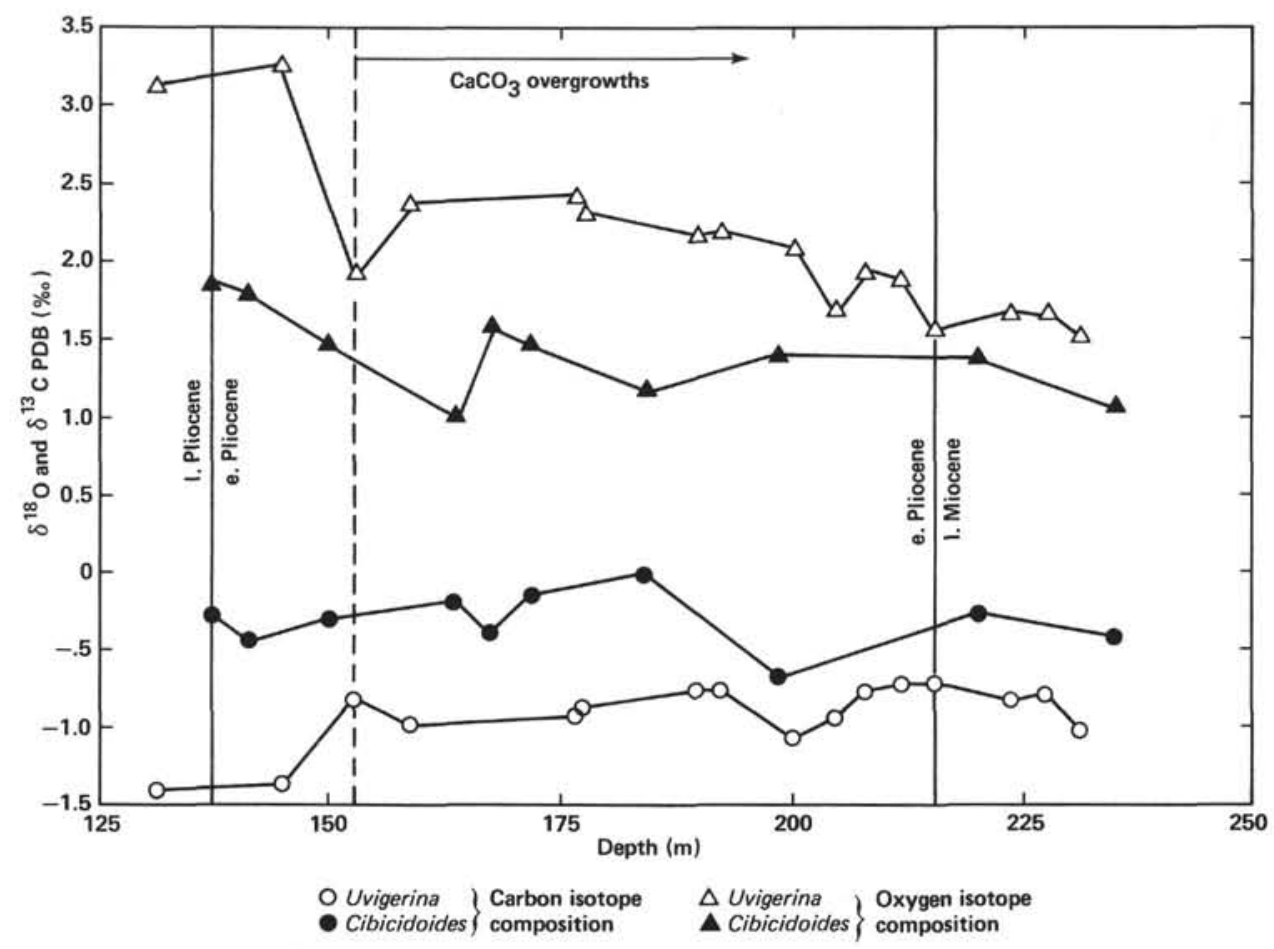

Figure 14. Carbon and oxygen isotopic composition of two genera of benthic foraminifera from Hole 504 .

with an initial $\delta^{18} \mathrm{O}$ of $-5 \%$. The reaction is assumed to take place at $50^{\circ} \mathrm{C}$ in carbonate sediment with $50 \%$ porosity. It can be shown that only $10 \%$ recrystallization is needed to change the $\delta^{18} \mathrm{O}$ of the pore water at depths from 230 to 260 meters to the values observed. A more complex model involving 10 to $40 \%$ recrystallization and the diffusion of ${ }^{18} \mathrm{O}$ out of the reaction zone is needed to explain the decrease in the $\delta^{18} \mathrm{O}$ values of the carbonate sediment (Figs. 13 and 14).

The latter model can be used to constrain the timing of the alteration in the basement and sediments that produced the $\delta^{18} \mathrm{O}$ profile. If the $\delta^{18} \mathrm{O}$ depletion in the sediment pore waters originated in the alteration of the basement and propagated into the sediments by diffusion, an approximately linear depletion profile with a minimum value at the basement contact would have preceded the onset of the $\delta^{18} \mathrm{O}$ reversal resulting from sediment diagenesis. The model indicates that about $1 \mathrm{~m}$.y. would be required for a profile to develop the degree of linearity displayed by that for Site 501/504 at depths above 235 meters (Fig. 9), assuming that the profile was initially vertical, as it is at the younger Site 505. As discussed earlier, the pore water profiles at Site 505 were interpreted to mean that the flow rate of relatively unreacted seawater through basement was too rapid relative to the rate of basalt-seawater reactions for the values of $\delta^{18} \mathrm{O}$ to shift away from $0 \%$. This condition apparently changed at Site 501/504 about 1 m.y. ago, so that the reaction rates in the basement exceeded flow rates and the $\delta^{18} \mathrm{O}$ of the basement waters shifted to about $-5 \%$.

The shift in $\delta^{18} \mathrm{O}$ of the sediment pore waters toward the heavier values resulting from sediment diagenesis has caused the diffusion profile above 235 meters to be cut off from its source of light ${ }^{18} \mathrm{O} /{ }^{16} \mathrm{O}$ in the basement.
Thus, the light values just above the uppermost chert are not being replenished at present and will tend to disappear with time via diffusion. That this has not yet happened to a significant extent constrains the timing of the diagenetic shift toward heavy values in the lower sediment pore waters. The abruptness of the $\delta^{18} \mathrm{O}$ reversal indicates that the diagenetic front that produced the reversal moved upward from the basement to its present position over a time period much shorter than the last 200,000 yr., according to our preliminary calculations. This diagenetic front, which is marked by carbonate recrystallization and chert formation, corresponds approximately to the $56^{\circ} \mathrm{C}$ isotherm. Thus, it would appear that the basal sediments became heated to this temperature only quite recently.

\section{ACKNOWLEDGMENTS}

This research was supported by National Science Foundation grants OCE 80-19056 (to MJM) and OCE-77-24819 and OCE 8024044 (to JRL). We wish to thank our colleagues Kirk Cochran, Frank Manheim, and Ed Sholkovitz for reviewing the manuscript. This is WHOI Contribution No. 5162.

\section{REFERENCES}

Gieskes, J. M., 1974. Interstitial water studies, Leg 25. In Simpson, E. S. W., Schlich, R., et al., Init. Repts. DSDP, 25: Washington (U.S. Govt. Printing Office), 361-394.

Keigwin, L. D., Jr., 1979. Late Cenozoic stable isotope stratigraphy and paleoceanography of DSDP sites from the East Equatorial and Central North Pacific Ocean. Earth Planet. Sci. Lett., 45: 361-382.

Lawrence, J. R. and Gieskes, J. M., 1981. Constraints on water transport and alteration in the oceanic crust from the isotopic composition of pore water. J. Geophys. Res., 86:7924-7934.

Lawrence, J. R., Gieskes, J., and Anderson, T. F., 1976. Oxygen isotope material balances calculations, Leg 35. In Hollister, C. D., Craddock, C., et al., Init. Repts. DSDP, 35: Washington (U.S. Govt. Printing Office), 507-512. 
Lawrence, J. R., Gieskes, J. M., and Broecker, W. S., 1975. Oxygen isotope and cation composition of DSDP pore waters and the alteration of Layer II basalts. Earth Planet. Sci. Lett., 27:1-10.

Lonsdale, P., and Klitgord, K. D., 1978. Structure and tectonic history of the eastern Panama Basin. Geol. Soc. Am. Bull., 89:981-999.

Luther, G. W., III, and Meyerson, A. L., 1975. Polarographic analysis of sulfate ion in seawater samples. Anal. Chem., 47:2058-2059.
McDuff, R. E., 1981. Major cation gradients in DSDP interstitial waters: the role of diffusive exchange between seawater and upper oceanic crust. Geochim. Cosmochim. Acta, 45:1705-1713.

Sayles, F. L., and Manheim, F. T., 1975. Interstitial solutions and diagenesis in deeply buried marine sediments: results from the Deep Sea Drilling Project. Geochim. Cosmochim. Acta, 39:103-127. 